\title{
Causes of Disputes in Palestine
}

\author{
Hussein Abu Zant ${ }^{1^{*}}$ \\ Civil Engineering Department, An-Najah National University, PO. Box 7 Nablus, Palestine.
}

\begin{abstract}
There are many causes of disputes between the owners and contractors. Since there are numerous conflicts between them, and each part hopes to achieve his aspiration. Disputes could be a result of contractors or owners, and other caused by general conditions, when the contractor being familiar with the causes of disputes, he will take all his precautions to avoid them. This paper will focus on causes of disputes to make all parties Familiar with these causes of disputes in order to minimize or to eliminate it if possible. The avoidance of disputes is very beneficial especially for the contractor to avoid the loss of money, time and the most important" his reputation".

In this paper disputes focused on the interactions between owner or his representation and the contractor. In this paper the researcher gathered data about the causing of disputes from different resources of references, websites, engineering offices (consultants), construction companies and engineers. The disputes were generated mainly from owners, contractors, and general conditions and circumstances.
\end{abstract}

The second step; the researcher designed the layout of questionnaire. It should be distributed to stakeholder such as construction companies, and engineering offices to fill the questionnaire. Then the questionnaire analyzed to recognize the main causes of disputes. In addition, the contribution of each part in causing disputes could be determined.

According to analyzed questionnaire; the most hazard and frequent causes of disputes could be highlighted. Since the most frequent cause of disputes become obvious, so the solutions for them could be determined.

Finally, the outcomes of analyzed questionnaire compose a list of remedial actions for each cause of disputes.

The outcomes of this paper show that the most frequent cause of disputes is the general conditions, while the contractor should pay more attention in project management especially in planning phase. In addition, the owner has to pay the contractor his rights without temporization and to make a rapid response for the questions of the contractor. Finally, the owner must avoid any contradiction in contract documents.

Keywords: Construction, Contract, Delay, Disputes, Variation, Palestine.

\section{INTRODUCTION}

Construction industry is the vital sector in Palestine. It is considered an essential requirement for economic activities $[1,2]$.
A dispute is defined as a conflict between two or more parties to achieve their interests and their claims or their rights, which are often conflicting. Since each part aims to achieve what he aims to fulfill his own beneficial interests.

A successful project that has no disputes or claims. The good management have to focus on disputes that has most probable and higher impacts to be occurred in project [3]. So, the good management of contractor will avoid the most hazard causes of disputes.

\section{I.I CAUSES OF DISPUTES}

Since disputes generated from missing or conflicting between the parties of the project, it must be defined to overcome the main resources of disputes. To minimize the causes of disputes, determination and definition of these disputes must be marked. There are many causes of dispute in construction projects. These causes being summarized by three definite categories, the first category is that disputes caused by contractor, other category caused by owner, and the third category caused by general conditions or caused by existing circumstances.

The Palestinian situation in West Bank is like the situation in Gaza Strip since they have nearly the same political situation. In Gaza Strip as noted from submitted in partial fulfillment of requirements for degree of master of science in construction management; the major causes of claims are; closure of borders due to political situation, design error or omission, suspension of work, shortage of material and high rising of its prices, and contract ambiguities [4].

\section{I.II OBSTACLES OF CONSTRUCTION CONTRACTS}

There are several obstacles faced the executing of contracts in Palestine. As a result of these obstacles the majority of contracts forced to be delayed. So, disputes arise in respect of delays. High competency between contractors forced the contractor to bid for very low price to win the tender. The severe low of contract price leads to high potential of disputes. In addition, there are several obstacles faced construction of contracts such as currency exchange rate fluctuation, postponed of owner's decision making, high number of contractors with respect to the lake of available projects, incremental of materials prices [5].

\section{I.III VARIATIONS IN CONTRACTS}

Variations are prime cause of construction disputes, particularly where there are a substantial number. The natural 
result of minimizing change orders in projects is to minimize or eliminate if possible, such change orders. There are several issues that cause change orders, conflicts between contract documents, none availability of materials needed in project, and financial issues for both contractor and owner are resources of change orders [6].

\section{I.IV CONTRACT DELAY}

Construction projects in Palestine suffers many problems due to political issues. Therefore, the majority of projects subjected to delay. The delay of project raised the disputes between contract parties. There are many factors may delay the finishing of project on time. Political uncertainty, scarcity of materials, and lack of regulation [7]. In addition, Owner may determine the duration of the project are not suitable with the size of the project work. Delays in project may be occurs from each part of agreement or from external forces such as the permits may delay, that's lead to delay to achieve project on time, laws or regulations that come into effect after the start of work which might impact the work, interference from the community surrounding the project, some projects are effect negatively on environment that's leads to interfere the environmental protection agencies that's may causes some delay in project, changes in prices of materials used in construction, currency fluctuations as happened in 2008 that's lead to distractive impact for the majority of contractors.

\section{I.V RESOLUTION OF DISPUTES}

Especially in large projects and due to complexity for such projects a high potential of disputes raised. The parties of contracts have more than scenarios to resolve their disputes. The court one of these scenarios. But it consumes more time and may be costly for all parties. The informal dispute resolution is preferred over litigation method [8]. The first method to resolve disputes begins from negotiations between contract parties, the second step in case the failed of negotiations is arbitration. In Palestine the informal negotiations are more efficient than litigation methods.

\section{QUESTIONNAIRE}

\section{II.I METHODS AND PROCEDURE}

Questionnaire was made to measure the degree of effectiveness for each cause. SPSS were used in the analysis and the results were presented in the following paragraph. The above questionnaire was corrected by four academic qualified staff members of An-Najah National University. All notes were taken and corrected, and the final issue of questionnaire was adopted and analyzed.

\section{II.II SAMPLING, INSTRUMENTATION, PROCEDURE}

The sample consisted of 30 companies in the construction sector in Palestine. The background of the study sample is varied in terms of personal information, companies' information and classification as shown in Tables (1) and (2) below.

Table 1: Distribution of Sample According to Study Independent Variables of the Employees

\begin{tabular}{|c|c|c|c|}
\hline Variable & Class & Frequency & Percentage $\%$ \\
\hline \multirow[t]{2}{*}{ Gender } & Male & 30 & 100.0 \\
\hline & Female & 0 & 0.0 \\
\hline \multirow{3}{*}{ Company Capital (JD) } & 5000- to $19999 \mathrm{JD}$ & 5 & 16.7 \\
\hline & 40000-59999 JD & 3 & 10.0 \\
\hline & 60000 and more & 22 & 73.3 \\
\hline \multirow{4}{*}{ Company Age } & $1-4$ years & 3 & 10.0 \\
\hline & $5-9$ years & 9 & 30.0 \\
\hline & $10-14$ years & 10 & 33.3 \\
\hline & 15 years and more & 8 & 26.7 \\
\hline & First & 13 & 43.3 \\
\hline \multirow{4}{*}{$\begin{array}{l}\text { Company Classification } \\
\text { According to Palestinian } \\
\text { Contractors Union(Class) }\end{array}$} & Second & 6 & 20.0 \\
\hline & Third & 6 & 20.0 \\
\hline & Fourth & 2 & 6.7 \\
\hline & Five & 3 & 10.0 \\
\hline \multirow{4}{*}{$\begin{array}{l}\text { Contractor's Academic } \\
\text { Qualification }\end{array}$} & School & 2 & 6.7 \\
\hline & Diploma & 2 & 6.7 \\
\hline & University & 25 & 83.3 \\
\hline & Other & 1 & 3.3 \\
\hline \multicolumn{2}{|l|}{ Total } & 30 & 100.0 \\
\hline
\end{tabular}




\section{Instrumentation}

To achieve the objectives of the study, the researchers used a 41-item questionnaire for construction companies' sample by using previous literature and the researcher's own experience in the field of Engineering. The questionnaire consisted of four sections; the first focused on demographic data of the respondents such gender, company capital, company age, company classification according to the Palestinian Contractors' Union a contractors' academic qualification. The second consisted of four questions about the reasons for disputes related to the contractor, reasons related to the owner, reasons related to other conditions and treatment of the dispute.

The scores of responses to each item were calculated according to a five-point Likert scale for the first three domains responses in which strongly agree $=5$ points, agree $=4$ points, neutral $=3$, disagree $=2$ points and strongly disagree $=1$ point, four - Likert scale for the last one in which High $=4$ points, medium $=3$ points, low $=2$ points, and has nothing to $\mathrm{do}=1$ point.

\section{II.III VALIDITY OF QUESTIONNAIRE}

To ensure the validity of the questionnaire, it was rated by a jury of experts in the field of engineering at An-Najah National University. The respondents' comments and the jury's suggestions were taken into consideration to modify and improve the questionnaire's content and wordings by omitting, adding or rephrasing which makes the number of items remained 41 items.

Reliability of the Questionnaire:

The reliability of the questionnaire as calculated through Cronbach Alpha formula for the total degree was (0.73) which is acceptable for conducting the research.

Procedure

The final draft of the questionnaire was given to company owners at West Bank. It took about five weeks for the instrument to be distributed, collected, and returned to the researchers. The total number of the returned questionnaires was 30. No questionnaire has been excluded as their responses were neither consistent nor complete.

\section{II.IV DATA ANALYSIS}

The data collected were analyzed using (SPSS-17) to provide answers to the questions of the study. Means, frequencies, standard deviations two independent sample T-test and OneWay ANOVA Test. To analyze the findings, the researchers used the following scales to represent the estimation level of sample responses:

$$
\begin{array}{ll}
\hline \text { 4.20 and more }-84.0 \% \text { and more } & \text { Very High } \\
\text { 2.40-4.19 }-68.0-83.8 \% & \text { High } \\
1-80-2.59-36.0-51.8 \% & \text { Moderate } \\
\text { Less than } 1.8-35.9 \% \text { and less } & \text { Low }
\end{array}
$$

\begin{tabular}{|ll|}
\hline 3.51 and more & High \\
$2.51-3.50$ & Moderate \\
Less than $2.5 \%$ & Low \\
\hline
\end{tabular}

\section{RESULT AND DISCUSSION}

This study aimed at identifying reasons for dispute between the contractor and the owner in Palestinian construction companies. It also aimed at identifying the effect of several variables on the responses. To accomplish the aims of the study, the researchers analyzed the data in accordance with the study questions and the results were as follows:

\section{III.I RESULTS RELATED TO THE FIRST QUESTION}

What is the degree of reasons for dispute between the contractor and the owner in Palestinian construction companies?

To answer this question, the researcher used means and 
International Journal of Engineering Research and Technology. ISSN 0974-3154, Volume 13, Number 10 (2020), pp. $2625-2636$

(C) International Research Publication House. https://dx.doi.org/10.37624/IJERT/13.10.2020.2625-2636

standard deviations and estimation level as shown in

following tables.

Table (2): Means, Standard Deviations and estimated level of the reasons for dispute between the contractor and the owner in Palestinian construction companies for the study domains and the total degree in descending order according to the mean.

\begin{tabular}{|c|c|c|c|c|c|c|}
\hline$\dot{\mathbf{z}}$ & 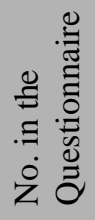 & 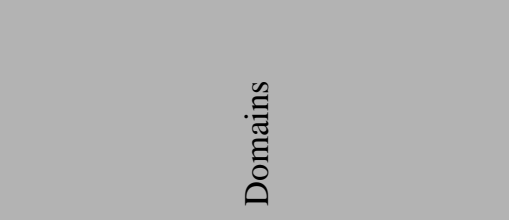 & 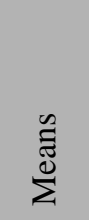 & 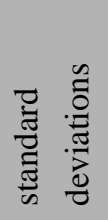 & 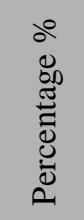 & 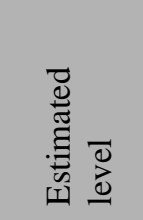 \\
\hline 1 & 3 & Reasons related to other conditions & 3.66 & 0.47 & 73.2 & High \\
\hline 2 & 2 & Reasons related to the owner & 3.16 & 0.47 & 63.2 & Moderate \\
\hline 3 & 1 & Reasons related to the contractor & 2.85 & 0.75 & 57.0 & Moderate \\
\hline \multicolumn{3}{|r|}{ Total } & 3.22 & 0.35 & 64.2 & Moderate \\
\hline
\end{tabular}

Table (2) shows that the total degree of the reasons for dispute between the contractor and the owner in Palestinian construction companies was (64.2) which suggest Moderate level of estimation. The highest mean was given to the domain
(Reasons related to other conditions). The lowest was for the domain (Reasons related to the contractor).

The following tables show the details:

Table (3): Means, Standard Deviations and estimated level of Means, Standard Deviations and estimated level of the reasons for dispute between the contractor and the owner in Palestinian construction companies for the first domain (Reasons related to the contractor) in descending order according to the mean.

\begin{tabular}{|c|c|c|c|c|c|c|}
\hline No. & $\begin{array}{l}\text { No. in the } \\
\text { Questionnaire }\end{array}$ & Item & Means & $\begin{array}{c}\text { standard } \\
\text { deviations }\end{array}$ & $\begin{array}{l}\text { Percentage } \\
\%\end{array}$ & $\begin{array}{l}\text { Estimated } \\
\text { level }\end{array}$ \\
\hline 1. & 9 & $\begin{array}{l}\text { The contractor doesn't depend on planning programs such as } \\
\text { (Primavera and M.S. Project) for implementing the project }\end{array}$ & 3.13 & 1.30 & 62.6 & Moderate \\
\hline 2. & 2 & The contractor doesn't read contract documents. & 3.10 & 1.26 & 62.0 & Moderate \\
\hline 3. & 5 & $\begin{array}{l}\text { The contractor is late in preparing required samples in order } \\
\text { to approve them by the supervisor. }\end{array}$ & 3.03 & 1.09 & 60.6 & Moderate \\
\hline 4. & 1 & $\begin{array}{l}\text { The contractor is late in delivering works to the supervising } \\
\text { engineer }\end{array}$ & 3.03 & 1.18 & 60.6 & Moderate \\
\hline 5. & 6 & The contractor is late in providing required substances & 2.83 & 0.94 & 56.6 & Moderate \\
\hline 6. & 7 & $\begin{array}{l}\text { The contractor is late in delivering bid items according to the } \\
\text { required specifications }\end{array}$ & 2.83 & 1.14 & 56.6 & Moderate \\
\hline 7. & 3 & $\begin{array}{l}\text { The contractor doesn't study the prices of items of the } \\
\text { contract well. }\end{array}$ & 2.76 & 1.16 & 55.2 & Moderate \\
\hline 8. & 4 & $\begin{array}{l}\text { The contractors don't understand the schemes well. He } \\
\text { doesn't study and compare them with lists of quantities. }\end{array}$ & 2.73 & 1.17 & 54.6 & Moderate \\
\hline 9. & 8 & $\begin{array}{l}\text { The contractor doesn't visit the worksite when pricing the } \\
\text { bid items. }\end{array}$ & 2.66 & 1.06 & 53.2 & Moderate \\
\hline 10. & 10 & $\begin{array}{l}\text { The contractor doesn't have technical experiences required } \\
\text { for implementing the project according to the detailed } \\
\text { specifications. }\end{array}$ & 2.40 & 1.13 & 48.0 & Low \\
\hline \multicolumn{3}{|r|}{ Total } & 2.85 & 0.75 & 57.0 & Moderate \\
\hline
\end{tabular}


International Journal of Engineering Research and Technology. ISSN 0974-3154, Volume 13, Number 10 (2020), pp. $2625-2636$

(C) International Research Publication House. https://dx.doi.org/10.37624/IJERT/13.10.2020.2625-2636

Table (3) shows that the total degree of the reasons for dispute between the contractor and the owner in Palestinian construction companies for the first domain (Reasons related to the contractor) was (57.0) which suggest moderate level of estimation. The highest mean was given to the item (The contractor doesn't depend on planning programs such as
(Primavera and M.S .Project) for implementing the project.). The lowest was for the item (The contractor doesn't have technical experiences required for implementing the project according to the detailed specifications.).

Table (4): means, Standard Deviations and estimated level of Means, Standard Deviations and estimated level of the reasons for dispute between the contractor and the owner in Palestinian construction companies for the second domain (Reasons related to the owner) in descending order according to the mean.

\begin{tabular}{|c|c|c|c|c|c|c|}
\hline No. & $\begin{array}{l}\text { No.in the } \\
\text { Questionnaire }\end{array}$ & Item & Means & $\begin{array}{c}\text { standard } \\
\text { deviations }\end{array}$ & $\begin{array}{l}\text { Percentage } \\
\%\end{array}$ & $\begin{array}{l}\text { Estimated } \\
\text { level }\end{array}$ \\
\hline 11. & 12 & $\begin{array}{l}\text { The owner doesn't give quick answer or decision related to } \\
\text { the contractor questions and some bid items }\end{array}$ & 3.80 & 0.88 & 76.0 & High \\
\hline 12. & 13 & The owner doesn't estimate the duration of the bid. & 3.53 & 0.93 & 70.6 & High \\
\hline 13. & 21 & $\begin{array}{l}\text { The owner doesn't understand some of engineering issues } \\
\text { required for implementing the project }\end{array}$ & 3.46 & 1.19 & 69.2 & High \\
\hline 14. & 20 & $\begin{array}{l}\text { The owner doesn't prepare spare money in case of additional } \\
\text { works }\end{array}$ & 3.33 & 1.09 & 66.6 & Moderate \\
\hline 15. & 16 & $\begin{array}{l}\text { The owner doesn't depend on the law in preparing and } \\
\text { interrupting the contract for implementing the project }\end{array}$ & 3.33 & 1.09 & 66.6 & Moderate \\
\hline 16. & 15 & $\begin{array}{l}\text { The owner doesn't follow up the project specifications } \\
\text { accurately }\end{array}$ & 3.13 & 1.04 & 62.6 & Moderate \\
\hline 17. & 19 & $\begin{array}{l}\text { The owner along with his representative doesn't prepare } \\
\text { detailed drawings }\end{array}$ & 3.06 & 1.20 & 61.2 & Moderate \\
\hline 18. & 18 & The owner doesn't prepare the contract well & 3.03 & 1.03 & 60.6 & Moderate \\
\hline 19. & 22 & The owner doesn't engage in some technical project details & 2.96 & 0.88 & 59.2 & Moderate \\
\hline 20. & 17 & $\begin{array}{l}\text { The owner doesn't use documentation during the supervising } \\
\text { in order to inform the contractor about the required } \\
\text { specifications according to the contract }\end{array}$ & 2.86 & 1.10 & 57.2 & Moderate \\
\hline 21 & 11 & $\begin{array}{l}\text { The owner doesn't change the bid qualities and quantities } \\
\text { during the implementation }\end{array}$ & 2.80 & 0.99 & 56.0 & Moderate \\
\hline 22 & 14 & The owner doesn't delay the payments & 2.70 & 0.98 & 54.0 & Moderate \\
\hline \multicolumn{3}{|c|}{ Total } & 3.16 & 0.47 & 63.2 & Moderate \\
\hline
\end{tabular}

Table (4) shows that the total degree of the reasons for dispute between the contractor and the owner in Palestinian construction companies for the second domain (Reasons related to the owner) was (63.0) which suggest moderate level of estimation. The highest mean was given to the item (The owner doesn't give quick answer or decision related to the contractor questions and some bid items). The lowest was for the item (The owner doesn't delay the payments.). 
International Journal of Engineering Research and Technology. ISSN 0974-3154, Volume 13, Number 10 (2020), pp. $2625-2636$

(C) International Research Publication House. https://dx.doi.org/10.37624/IJERT/13.10.2020.2625-2636

Table (5): Means, Standard Deviations and estimated level of Means, Standard Deviations and estimated level of the reasons for dispute between the contractor and the owner in Palestinian construction companies for the third domain (Reasons related to the other conditions) in descending order according to the mean.

\begin{tabular}{|c|c|c|c|c|c|c|}
\hline No. & $\begin{array}{l}\text { No. in the } \\
\text { Questionnaire }\end{array}$ & Item & Means & $\begin{array}{c}\text { standard } \\
\text { deviations }\end{array}$ & $\begin{array}{c}\text { Percentage } \\
\%\end{array}$ & $\begin{array}{l}\text { Estimated } \\
\text { level }\end{array}$ \\
\hline 23. & 23 & rising prices of the substances & 4.26 & 0.78 & 85.2 & $\begin{array}{l}\text { Very } \\
\text { High }\end{array}$ \\
\hline 24. & 25 & Instability of exchange rate of the project currency & 4.16 & 0.79 & 83.2 & High \\
\hline 25. & 24 & Bad weather which causes obstacles for the contractor & 4.06 & 0.86 & 81.2 & High \\
\hline 26. & 30 & $\begin{array}{l}\text { Unavailability of technical labor required for } \\
\text { implementing the project }\end{array}$ & 3.66 & 1.06 & 73.2 & High \\
\hline 27. & 29 & $\begin{array}{l}\text { Difficulty of finding modern local technologies in } \\
\text { order to implement the project according to the } \\
\text { specific requirements }\end{array}$ & 3.43 & 1.16 & 68.6 & High \\
\hline 28. & 27 & $\begin{array}{l}\text { Difficulty of entering substances to the worksite } \\
\text { caused by geographical conditions or Israeli check } \\
\text { points }\end{array}$ & 3.36 & 1.03 & 67.2 & Moderate \\
\hline 29. & 26 & $\begin{array}{l}\text { Difficulty of labor entering the worksite caused by } \\
\text { political or geographical reasons }\end{array}$ & 3.33 & 1.02 & 66.6 & Moderate \\
\hline 30. & 28 & $\begin{array}{l}\text { Unavailability of required substances in the local } \\
\text { markets }\end{array}$ & 3.03 & 0.99 & 60.6 & Moderate \\
\hline \multicolumn{3}{|l|}{ Total } & 3.66 & 0.47 & 73.2 & High \\
\hline
\end{tabular}

Table (5) shows that the total degree of the reasons for dispute between the contractor and the owner in Palestinian construction companies for the third domain (Reasons related to other conditions) was (73.2) which suggest high level of estimation. The highest mean was given to the item (High prices of the substances). The lowest was for the item (Unavailability of required substances in the local markets).

\section{III.II RESULTS RELATED TO SECOND QUESTION}

Are here significant statistical differences at $(\alpha=0.05)$ in the response's degree of the reasons for dispute between the contractor and the owner in Palestinian construction companies attributed to the variables of company capital, company age, company classification according to the Palestinian Contractors' Union a contractors' academic qualification?

To answer this question, One Way ANOVA test was used and the tables below show the results:

\section{Results related to the company capital}

Table (6): frequencies, Means and Standards Deviations of the reasons for dispute between the contractor and the owner in Palestinian construction companies attributed to the variables of company capital

\begin{tabular}{|l|c|c|c|c|}
\hline \multicolumn{2}{|l|}{ Company capital (Total Degree) } & N & Mean & S. D \\
\hline $\begin{array}{l}\text { The reasons for } \\
\text { dispute between } \\
\text { the contractor } \\
\text { and the owner in } \\
\begin{array}{l}\text { Palestinian } \\
\text { construction } \\
\text { companies } \\
\text { attributed to the } \\
\text { variables of } \\
\text { company capital }\end{array}\end{array}$ & 5000 - to 19999 JD & 5 & 3.30 & 0.38 \\
\cline { 2 - 5 } & 60000 and more & 22 & 3.23 & 0.36 \\
\cline { 2 - 5 } & Total & 30 & 3.22 & 0.35 \\
\hline
\end{tabular}


International Journal of Engineering Research and Technology. ISSN 0974-3154, Volume 13, Number 10 (2020), pp. $2625-2636$

(C) International Research Publication House. https://dx.doi.org/10.37624/IJERT/13.10.2020.2625-2636

Table (7): results of One Way ANOVA of the reasons for dispute between the contractor and the owner in Palestinian construction companies attributed to the variables of company capital

\begin{tabular}{|c|c|c|c|c|c|c|}
\hline $\begin{array}{l}\text { the reasons for dispute } \\
\text { between the contractor and } \\
\text { the owner in Palestinian } \\
\text { construction companies }\end{array}$ & Source of variance & $\begin{array}{l}\text { Sum of } \\
\text { Squares }\end{array}$ & do & Mean Square & F & Sig. \\
\hline \multirow{3}{*}{$\begin{array}{l}\text { Reasons related to the } \\
\text { contractor }\end{array}$} & Between Groups & 0.961 & 2 & 0.480 & \multirow[t]{3}{*}{0.824} & \multirow[t]{3}{*}{0.450} \\
\hline & Within Groups & 15.754 & 27 & \multirow[t]{2}{*}{0.583} & & \\
\hline & Total & 16.715 & 29 & & & \\
\hline \multirow{3}{*}{ Reasons related to the owner } & Between Groups & 0.758 & 2 & 0.379 & \multirow[t]{3}{*}{1.785} & \multirow[t]{3}{*}{0.187} \\
\hline & Within Groups & 5.735 & 27 & \multirow[t]{2}{*}{0.212} & & \\
\hline & Total & 6.493 & 29 & & & \\
\hline \multirow{3}{*}{$\begin{array}{l}\text { Reasons related to other } \\
\text { conditions }\end{array}$} & Between Groups & .926 & 2 & 0.463 & \multirow[t]{3}{*}{2.190} & \multirow[t]{3}{*}{0.131} \\
\hline & Within Groups & 5.709 & 27 & \multirow[t]{2}{*}{0.211} & & \\
\hline & Total & 6.635 & 29 & & & \\
\hline \multirow{3}{*}{ Total } & Between Groups & 0.089 & 2 & 0.044 & \multirow[t]{3}{*}{0.336} & \multirow[t]{3}{*}{0.717} \\
\hline & Within Groups & 3.562 & 27 & \multirow[t]{2}{*}{0.132} & & \\
\hline & Total & 3.651 & 29 & & & \\
\hline
\end{tabular}

* The mean difference is significant at the 0.05 level.

Table (7) shows that there are no statistical significant differences at $(\alpha=0.05)$ about the reasons for dispute between the contractor and the owner in Palestinian construction companies attributed to the variables of company capital. The significant value was (0.717) which is more than (0.05). Also, no statistical significant differences at $(\alpha=0.05)$ about the reasons for dispute between the contractor and the owner in Palestinian construction companies attributed to the variables of company capital in the three domains.
Table (8): frequencies, Means and Standards Deviations of the reasons for dispute between the contractor and the owner in Palestinian construction companies attributed to the variables of company age

\begin{tabular}{|l|l|c|c|c|}
\hline \multicolumn{2}{|l|}{ Company age (Total Degree) } & $\mathrm{N}$ & Mean & S. D \\
\hline \multirow{2}{*}{$\begin{array}{l}\text { The reasons for } \\
\text { dispute between } \\
\text { the contractor and } \\
\text { the owner in } \\
\text { Palestinian } \\
\text { construction } \\
\text { companies }\end{array}$} & $1-4$ years & 3 & 3.31 & 0.56 \\
\cline { 2 - 5 } & $10-14$ years & 10 & 3.26 & 0.32 \\
\cline { 2 - 5 } & 15 years and more & 8 & 3.18 & 0.47 \\
\cline { 2 - 5 } & Total & 30 & 3.22 & 0.35 \\
\hline
\end{tabular}


International Journal of Engineering Research and Technology. ISSN 0974-3154, Volume 13, Number 10 (2020), pp. $2625-2636$

(C) International Research Publication House. https://dx.doi.org/10.37624/IJERT/13.10.2020.2625-2636

Table (9): results of One Way ANOVA of the reasons for dispute between the contractor and the owner in Palestinian construction companies attributed to the variables of company age

\begin{tabular}{|c|c|c|c|c|c|c|}
\hline $\begin{array}{l}\text { the reasons for dispute } \\
\text { between the contractor and } \\
\text { the owner in Palestinian } \\
\text { construction companies }\end{array}$ & $\begin{array}{l}\text { Source of } \\
\text { variance }\end{array}$ & $\begin{array}{l}\text { Sum of } \\
\text { Squares }\end{array}$ & do & Mean Square & $\mathrm{F}$ & Sig. \\
\hline \multirow[t]{3}{*}{$\begin{array}{l}\text { Reasons related to the } \\
\text { contractor }\end{array}$} & $\begin{array}{l}\text { Between } \\
\text { Groups }\end{array}$ & 0.068 & 3 & 0.023 & \multirow[t]{3}{*}{0.035} & \multirow[t]{3}{*}{0.991} \\
\hline & Within Groups & 16.647 & 26 & \multirow[t]{2}{*}{0.640} & & \\
\hline & Total & 16.715 & 29 & & & \\
\hline \multirow[t]{3}{*}{$\begin{array}{l}\text { Reasons related to the } \\
\text { owner }\end{array}$} & $\begin{array}{l}\text { Between } \\
\text { Groups }\end{array}$ & 0.675 & 3 & 0.225 & \multirow[t]{3}{*}{1.006} & \multirow[t]{3}{*}{0.406} \\
\hline & Within Groups & 5.818 & 26 & \multirow[t]{2}{*}{0.224} & & \\
\hline & Total & 6.493 & 29 & & & \\
\hline \multirow[t]{3}{*}{$\begin{array}{l}\text { Reasons related to other } \\
\text { conditions }\end{array}$} & $\begin{array}{l}\text { Between } \\
\text { Groups }\end{array}$ & 0.394 & 3 & 0.131 & \multirow[t]{3}{*}{0.547} & \multirow[t]{3}{*}{0.654} \\
\hline & Within Groups & 6.241 & 26 & \multirow[t]{2}{*}{0.240} & & \\
\hline & Total & 6.635 & 29 & & & \\
\hline \multirow[t]{3}{*}{ Total } & $\begin{array}{l}\text { Between } \\
\text { Groups }\end{array}$ & 0.052 & 3 & 0.017 & \multirow[t]{3}{*}{0.125} & \multirow[t]{3}{*}{0.945} \\
\hline & Within Groups & 3.599 & 26 & \multirow[t]{2}{*}{0.138} & & \\
\hline & Total & 3.651 & 29 & & & \\
\hline
\end{tabular}

* The mean difference is significant at the 0.05 level.

Table (9) Shows that there are no statistical significant differences at $(\alpha=0.05)$ about the reasons for dispute between the contractor and the owner in Palestinian construction companies attributed to the variables of company age. The significant value was $(0.945)$ which is more than(0.05). Also, no statistical significant differences at $(\alpha=0.05)$ about the reasons for dispute between the contractor and the owner in Palestinian construction companies attributed to the variables of company capital in the three domains.

\section{Results related to the company classification}

Table (10): frequencies, Means and Standards Deviations of the reasons for dispute between the contractor and the owner in Palestinian construction companies attributed to the variables of company classification

\begin{tabular}{|l|l|l|l|l|}
\hline \multicolumn{2}{|l|}{$\begin{array}{l}\text { Company classification } \\
\text { (Total Degree) }\end{array}$} & $\mathrm{N}$ & Mean & S. D \\
\hline $\begin{array}{l}\text { The reasons for dispute } \\
\text { between the contractor } \\
\text { and the owner in } \\
\text { Palestinian construction } \\
\text { companies }\end{array}$ & First & 13 & 3.33 & 0.34 \\
\cline { 2 - 6 } & Second & 6 & 2.91 & 0.27 \\
\cline { 2 - 6 } & Fourth & 2 & 3.39 & 0.43 \\
\cline { 2 - 6 } & Five & 3 & 3.30 & 0.37 \\
\cline { 2 - 6 } & Total & 30 & 3.22 & 0.35 \\
\hline
\end{tabular}


International Journal of Engineering Research and Technology. ISSN 0974-3154, Volume 13, Number 10 (2020), pp. $2625-2636$

(C) International Research Publication House. https://dx.doi.org/10.37624/IJERT/13.10.2020.2625-2636

Table (11): results of One-Way ANOVA of the reasons for dispute between the contractor and the owner in Palestinian construction companies attributed to the variables of company classification

\begin{tabular}{|c|c|c|c|c|c|c|}
\hline $\begin{array}{l}\text { the reasons for dispute between the } \\
\text { contractor and the owner in } \\
\text { Palestinian construction } \\
\text { companies }\end{array}$ & $\begin{array}{l}\text { Source of } \\
\text { variance }\end{array}$ & $\begin{array}{l}\text { Sum of } \\
\text { Squares }\end{array}$ & do & Mean Square & $\mathrm{F}$ & Sig. \\
\hline \multirow[t]{3}{*}{ Reasons related to the contractor } & $\begin{array}{l}\text { Between } \\
\text { Groups }\end{array}$ & 1.638 & 4 & 0.410 & \multirow[t]{3}{*}{0.679} & \multirow[t]{3}{*}{0.613} \\
\hline & $\begin{array}{l}\text { Within } \\
\text { Groups }\end{array}$ & 15.076 & 25 & \multirow[t]{2}{*}{0.603} & & \\
\hline & Total & 16.715 & 29 & & & \\
\hline \multirow[t]{3}{*}{ Reasons related to the owner } & $\begin{array}{l}\text { Between } \\
\text { Groups }\end{array}$ & 1.418 & 4 & 0.355 & \multirow[t]{3}{*}{1.747} & \multirow[t]{3}{*}{0.171} \\
\hline & $\begin{array}{l}\text { Within } \\
\text { Groups }\end{array}$ & 5.075 & 25 & \multirow[t]{2}{*}{0.203} & & \\
\hline & Total & 6.493 & 29 & & & \\
\hline \multirow[t]{3}{*}{$\begin{array}{l}\text { Reasons related to other } \\
\text { conditions }\end{array}$} & $\begin{array}{l}\text { Between } \\
\text { Groups }\end{array}$ & 0.255 & 4 & 0.064 & \multirow[t]{3}{*}{0.250} & \multirow[t]{3}{*}{0.907} \\
\hline & $\begin{array}{l}\text { Within } \\
\text { Groups }\end{array}$ & 6.381 & 25 & \multirow[t]{2}{*}{0.255} & & \\
\hline & Total & 6.635 & 29 & & & \\
\hline \multirow[t]{3}{*}{ Total } & $\begin{array}{l}\text { Between } \\
\text { Groups }\end{array}$ & 0.813 & 4 & 0.203 & \multirow[t]{3}{*}{1.790} & \multirow[t]{3}{*}{0.162} \\
\hline & $\begin{array}{l}\text { Within } \\
\text { Groups }\end{array}$ & 2.838 & 25 & \multirow[t]{2}{*}{0.114} & & \\
\hline & Total & 3.651 & 29 & & & \\
\hline
\end{tabular}

* The mean difference is significant at the 0.05 level.

Table (11) shows that there are no statistical significant differences at $(\alpha=0.05)$ about the reasons for dispute between the contractor and the owner in Palestinian construction companies attributed to the variables of company classification. The significant value was (0.162) which is more than (0.05). Also, no statistical significant differences at $(\alpha=0.05)$ about the reasons for dispute between the contractor and the owner in Palestinian construction companies attributed to the variables of company capital in the three domains.

\section{Results related to the contractor qualification}

Table (12): frequencies, Means and Standards Deviations of the reasons for dispute between the contractor and the owner in Palestinian construction companies attributed to the variables of contractor qualification

\begin{tabular}{|l|c|c|c|c|}
\hline \multicolumn{2}{|l|}{$\begin{array}{l}\text { Contractor qualification } \\
\text { (Total Degree) }\end{array}$} & $\mathrm{N}$ & Mean & S. D \\
\hline $\begin{array}{l}\text { The reasons for } \\
\text { dispute between } \\
\text { the contractor and } \\
\text { the owner in }\end{array}$ & School & 2 & 3.310 & 0.03 \\
\cline { 2 - 6 } $\begin{array}{l}\text { Palestinian } \\
\text { construction } \\
\text { companies }\end{array}$ & University & 25 & 3.250 & 0.35 \\
\cline { 2 - 6 } & Other & 1 & 2.580 & -------- \\
\cline { 2 - 6 } & Total & 30 & 3.22 & 0.35 \\
\hline
\end{tabular}


International Journal of Engineering Research and Technology. ISSN 0974-3154, Volume 13, Number 10 (2020), pp. $2625-2636$

(C) International Research Publication House. https://dx.doi.org/10.37624/IJERT/13.10.2020.2625-2636

Table (13): results of One Way ANOVA of the reasons for dispute between the contractor and the owner in Palestinian construction companies attributed to the variables of contractor qualification

\begin{tabular}{|c|c|c|c|c|c|c|}
\hline $\begin{array}{l}\text { The reasons for dispute } \\
\text { between the contractor and the } \\
\text { owner in Palestinian } \\
\text { construction companies }\end{array}$ & $\begin{array}{l}\text { Source of } \\
\text { variance }\end{array}$ & $\begin{array}{l}\text { Sum of } \\
\text { Squares }\end{array}$ & do & $\begin{array}{l}\text { Mean } \\
\text { Square }\end{array}$ & $\mathrm{F}$ & Sig. \\
\hline \multirow{3}{*}{$\begin{array}{l}\text { Reasons related to the } \\
\text { contractor }\end{array}$} & Between Groups & 0.688 & 3 & 0.229 & \multirow[t]{3}{*}{0.372} & \multirow[t]{3}{*}{0.774} \\
\hline & Within Groups & 16.027 & 26 & \multirow[t]{2}{*}{0.616} & & \\
\hline & Total & 16.715 & 29 & & & \\
\hline \multirow{3}{*}{ Reasons related to the owner } & Between Groups & 1.177 & 3 & 0.392 & \multirow[t]{3}{*}{1.918} & \multirow[t]{3}{*}{0.151} \\
\hline & Within Groups & 5.316 & 26 & \multirow[t]{2}{*}{0.204} & & \\
\hline & Total & 6.493 & 29 & & & \\
\hline \multirow{3}{*}{$\begin{array}{l}\text { Reasons related to other } \\
\text { conditions }\end{array}$} & Between Groups & 0.479 & 3 & 0.160 & \multirow[t]{3}{*}{0.675} & \multirow[t]{3}{*}{0.575} \\
\hline & Within Groups & 6.156 & 26 & \multirow[t]{2}{*}{0.237} & & \\
\hline & Total & 6.635 & 29 & & & \\
\hline \multirow{3}{*}{ Total } & Between Groups & 0.462 & 3 & 0.154 & \multirow[t]{3}{*}{1.256} & \multirow[t]{3}{*}{0.310} \\
\hline & Within Groups & 3.189 & 26 & \multirow[t]{2}{*}{0.123} & & \\
\hline & Total & 3.651 & 29 & & & \\
\hline
\end{tabular}

* The mean difference is significant at the 0.05 level.

Table (11) shows that there are no statistical significant differences at $(\alpha=0.05)$ about the of the reasons for dispute between the contractor and the owner in Palestinian construction companies attributed to the variables of company classification. The significant value was (0.310) which is more than (0.05). Also, no statistical significant differences at $(\alpha=0.05)$ about the reasons for dispute between the contractor and the owner in Palestinian construction companies attributed to the variables of company capital in the three domains.

Results related to the Third Question. What is the degree of procedures for solving dispute between the contractor and the owner in Palestinian construction companies?

To answer this question, the researcher used means and standard deviations and estimation level according to the following scale:

3.51 and more High

$2.51-3.50$

Moderate

Less than $2.5 \% \quad$ Low

\section{The results are shown in following table.}

Table (14): means, Standard Deviations, estimated level of Means, Standard Deviations, and estimated level of degree of procedures for solving dispute between the contractor and the owner in Palestinian construction companies are in descending order according to the mean.

\begin{tabular}{|c|c|l|c|c|c|}
\hline No. & $\begin{array}{c}\text { No.in the } \\
\text { Questionnaire }\end{array}$ & Item & $\begin{array}{c}\text { Means } \\
\text { standard } \\
\text { deviations }\end{array}$ & $\begin{array}{c}\text { Estimated } \\
\text { level }\end{array}$ \\
\hline 1. & 5 & Paying the whole payment from the owner to the contractor & 3.76 & 0.43 & Very High \\
\hline 2. & 2 & Contractor's good management and planning & 3.76 & 0.50 & High \\
\hline 3. & 1 & Studying the bid documents correctly by the contractor or his & 3.73 & 0.52 & High \\
\hline
\end{tabular}


International Journal of Engineering Research and Technology. ISSN 0974-3154, Volume 13, Number 10 (2020), pp. $2625-2636$

(C) International Research Publication House. https://dx.doi.org/10.37624/IJERT/13.10.2020.2625-2636

\begin{tabular}{|c|c|c|c|c|c|}
\hline No. & $\begin{array}{l}\text { No.in the } \\
\text { Questionnaire }\end{array}$ & Item & Means & $\begin{array}{c}\text { standard } \\
\text { deviations }\end{array}$ & $\begin{array}{l}\text { Estimated } \\
\text { level }\end{array}$ \\
\hline & & representative who prices them. & & & \\
\hline 4. & 7 & $\begin{array}{l}\text { Good preparing for the bid documents by the owner it orders to } \\
\text { remove any contradiction with the list of quantities }\end{array}$ & 3.66 & 0.60 & High \\
\hline 5. & 11 & $\begin{array}{l}\text { Providing owner's studied responses about the contractor's } \\
\text { questions which cannot hinder the project items }\end{array}$ & 3.60 & 0.56 & High \\
\hline 6. & 10 & $\begin{array}{l}\text { Documentation Commitment of all contract parties in } \\
\text { implementing the project items }\end{array}$ & 3.56 & 0.72 & High \\
\hline 7. & 3 & Pre-preparing of samples required for the project & 3.53 & 0.62 & High \\
\hline 8. & 9 & $\begin{array}{l}\text { Not making changes in the project items by the owner either in } \\
\text { specification or quantities }\end{array}$ & 3.43 & 0.62 & Moderate \\
\hline 9. & 8 & $\begin{array}{l}\text { Contractor's commitment with quality criteria in implementing } \\
\text { the project according to the engineering specifications }\end{array}$ & 3.40 & 0.727 & Moderate \\
\hline 10. & 4 & $\begin{array}{l}\text { Providing project substances by the contractor previously in } \\
\text { order to know the transportation costs }\end{array}$ & 3.26 & 0.909 & Moderate \\
\hline 11. & 6 & $\begin{array}{l}\text { Visiting the project by the contractor in order to calculate the } \\
\text { transportation costs }\end{array}$ & 3.23 & 0.72 & Moderate \\
\hline \multicolumn{3}{|l|}{ Total } & 3.54 & 0.389 & High \\
\hline
\end{tabular}

Table (5) shows that the total degree of degree of procedures for solving dispute between the contractor and the owner in Palestinian construction companies was (3.54) which suggest high level of estimation. The highest mean was given to the item (Paying the whole payment from the owner to the contractor).The lowest was for the item (Visiting the project by the contractor in order to calculate the transportation costs.).

\section{ANALYSIS BASED ON SPSS}

According to Table 2 shows that the highest degree was affected the disputes was (reasons related to other conditions). This result matches the existence conditions in Palestine,sinceitoccupiedbyIsraelsolders. Thissituationcauseds everalproblemswhich affect the process and progressive of projects in Palestine.

In reference to Table 3 shows that the total degree of the reasons for disputes between the contractor and the owner is justified by the lack of planning programs that should be proceed and adopted by contractor. The main issue caused by contractor as resulted from questionnaire is the lack of planning this result agrees with the most of contractors, since they didn't adopt a software program such as primavera, MS project, or other programs. Besides, the majority of companies or contractors did not have such planning department or any specialized agencies to adopt such software planning programs.

As shown in Table 4, the main issue caused by owner that produced from the disputes between owner and contractor was the late answers for the contractor questions about any conflicts may be raised. In formal or organizational project, the late answers and any explanations needed from owner will consumed high period of time, this caused the waste time for contractor which may resulted in liquidates damages upon contractor. Therefore, this point represents a major cause of disputes.

With reference to Table 5, this table discusses the causes of disputes between the owner and contractor. The main item that has the highest effect is the rising prices of substances. The high competitions between large numbers of contractors lead to very lowering prices of contracts. Since there are few projects available in Palestine. The fewer projects justified by the existence conditions and bad economic sector in occupied territories. This situation forced the high number of contractors to struggle to win the tender even in very low prices.

According to Table 6, shows that the highest causing of disputes are the companies of lower capitals, this is a reasonable conclusion, because it is obvious that these companies lack of staff to make a needed software program. In addition, the financial conditions are not sufficient to overcome or support any trouble may face such companies.

As shown in Table 8, the highest causing of disputes are the companies of lower age (1-4) year, because they have insufficient experience.

With reference to Table 10, the main Company classification that has the highest effectiscategoryNo.1(first class),categoryNo.1 which executes a project with high cost, and usually the project of multi activists will have complex aspects, these projects will be executed with a high time period. The long period of time for projects and multi activities will have a high potential of disputes. 
Table 12 shows that, the highest category will cause disputes of companies that administrated by lower education, this is because they have lower education to focus on planning. In addition, these companies will not care with software programs.

\section{CONCLUSION}

1) The main causes of disputes are those related to general conditions.

2) The main cause of disputes relating to contractor is lack of planning programs.

3) The main cause of disputes relating to owner is the late answers to the contractor's questions and interpretations.

4) The main cause of disputes relating to other conditions is an increment of the cost of substances.

5) The highest causes of disputes are the companies of lower capitals

6) The highest causing of disputes are the companies of lower age (1-4)year

7) The main company classification that has the highest effect on causes of disputes is category No. 1 (first class)

8) The highest category will have caused disputes of companies that administrated by lower education

\section{RECOMMENDATION}

The research focused on the causes of disputes. Questioner has made to highlight the main causes of disputes. The contractors and owners should avoid these causes to mitigate any conflicts and problems.

Depending on the analysis of questioner the following recommendations should be taken in consideration.

1) The contractor should take care and doing a high effort in planning stage of project depending on any software program such as primavera.

2) The contractor should read all documents, and compare between bill of quantities and drawings to avoid any conflicts. This will affect also the reasonable price, since the contractor must know well all specifications when he read and study the bid documents.

3) The owner should give studied responses against the contractor's questions.

4) The owner should pay for contractor all his deserved payments on time, this enable the contactor to continue his work and the financial issues will not make any obstacles for progressive of work.

\section{REFERENCES}

[1] Enshassi, Adnan, Choudhry, Rafiq M,\& El-Ghandour, Said (2008). Owners' Perception towards Causes of Claims on Construction Projects in Palestine. Arab Gulf Journal of Scientific Research, Volume: 26, Number: 3, http://hdl.handle.net/20.500.12358/26459
[2] Hassouna, F. M., \& Jung, Y. W. (2020). Developing a Higher Performance and Less Thickness Concrete Pavement: Using a Nonconventional Concrete Mixture. Advances in Civil Engineering, 2020, 1-8. doi:10.1155/2020/8822994.

[3] K. Mohan M. (2003). Conflicts, claims and disputes in construction. Enginering Construction and Arciticrural Management. Volume 4, Issue 2, Page:95-111

[4] Alloh, Kamal Ouda (2014). Investigating Of Factors Causes Claims Creation in Construction Projects in the Gaza Strip- Palestine. Islamic University Journal. http://hdl.handle.net/20.500.12358/19128

[5] I. J. Shweiki. (2013). Construction Contracting Management Obstacles in Palestine. An-Najah National University, Nablus, Palestine.

[6] Mahamid, Ibrahim. (2017). Effect of change orders on rework in highway projects in Palestine. Journal of Financial Management of Property and Construction. 22. 62-76. 10.1108/JFMPC-03-2016-0015.

[7] Enshassi, Adnan \& Abdul-Aziz, A.-R \& Abushaban, Saleh. (2011). PERFORMANCE OF CONSTRUCTION PROJECTS: PERCEPTION OF OWNERS IN PALESTINE. 16.

[8] Enshassi, Adnan,\& Abu Rass, Ahmad (2008). Dispute resolution practices in the construction industry in Palestine. International Conference on Multi-National Construction Projects. China, http://hdl.handle.net/20. $500.12358 / 26457$ 